\title{
How Entrepreneurial Orientation Stimulates Different Types of Knowledge in the Internationalisation Process of Firms from Poland?
}

\author{
Agnieszka Głodowska, Marek Maciejewski, Krzysztof Wach
}

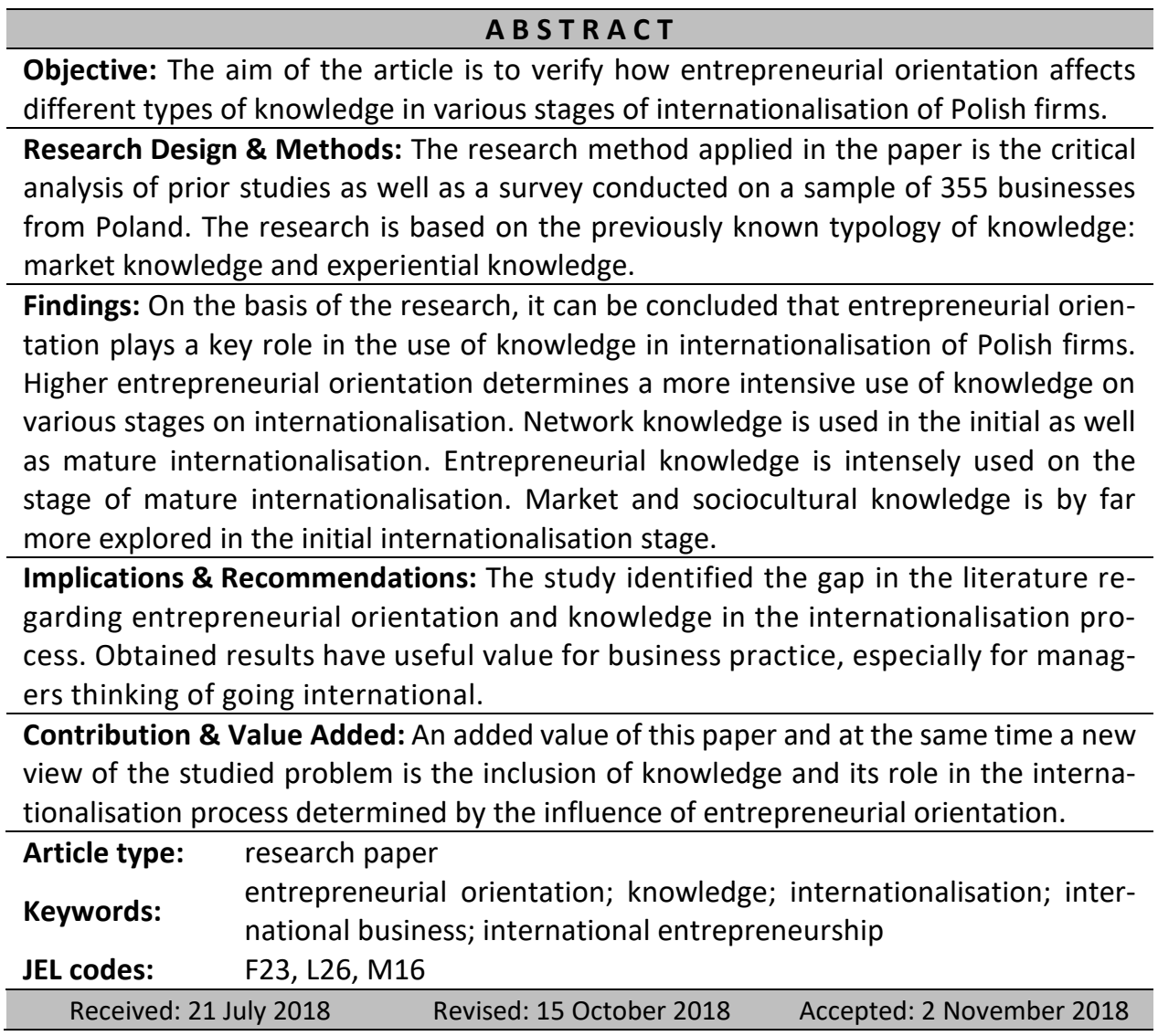

\section{Suggested citation:}

Głodowska, A., Maciejewski, M., \& Wach, K. (2019). How Entrepreneurial Orientation Stimulates Different Types of Knowledge in the Internationalisation Process of Firms from Poland?. Entrepreneurial Business and Economics Review, 7(1), 61-73. https://doi.org/10.15678/EBER.2019.070104 


\section{INTRODUCTION}

Entrepreneurial orientation in the international approach is a research problem systematically developed within studies on international entrepreneurship (Maciejewski \& Wach, 2019; Wach, 2017a, 2017b; 2018). In this article entrepreneurial orientation refers to the process of the internationalisation of firms, which is a substantial contribution to research into internationalisation understood as an entrepreneurial process, or to be more exact, entrepreneurial internationalisation (Wach, Głodowska, \& Maciejewski, 2018; Głodowska, Maciejewski, \& Wach, 2019). An added value of this article and the same time a new view of the studied problem is the inclusion of knowledge and its role in the internationalisation process determined by the influence of entrepreneurial orientation.

Therefore, the aim of the article is to verify how entrepreneurial orientation affects different types of knowledge in various stages of the internationalisation process on the basis of Polish businesses. The research method applied in the theoretical part is critical analysis of previous literature. In the empirical part, quantitative methods were used to present research results from survey conducted on a sample of 355 businesses from Poland.

The article is structured as follows. In the next section, the literature review of prior studies is presented. In the third section, the research methodology used in the study is explained. The results are discussed in the fourth section. The last section summarises our empirical findings, indicates the limitations of the study and recommendations for further research.

\section{LITERATURE REVIEW}

The connection of entrepreneurial orientation and knowledge in the internationalisation process can be understood differently on the theoretical basis. The entrepreneurial orientation itself is perceived as a strategic construction derived from the concept of strategic management (Gawet, 2015). Transposing this term to the international level resulted from the development of the international entrepreneurship idea. The new term was created as international entrepreneurial orientation explicated from the three basic components of entrepreneurial orientation: innovativeness, proactiveness and capability of risk-taking (McDougall \& Oviatt, 2000; Knight, 2001). Knowledge as a driving force of internationalisation is noticed in all internationalisation theories: conventional and alternative, as well as macroeconomic and microeconomic models. Its special importance is accented in the concepts which treat internationalisation as an entrepreneurial process (Autio, 2017; Matiusinaite \& Sekliuckiene, 2015). Therefore, it can be assumed that the theoretical premises of combining entrepreneurial orientation and knowledge in the internationalisation process have common ground in the international entrepreneurship concept which integrates the aspects of international business, entrepreneurship and strategic management. Thus, on the grounds of theory, it is appropriate to associate entrepreneurial orientation and knowledge with the internationalisation process, but in the existing studies those issues functioned as individual research problems, not related directly.

Entrepreneurial orientation in itself has been one of the most important research topics within research into entrepreneurship since as early as late 1980s (Al Mamun et al., 2017; Kumar et al., 2018), but in the international dimension it was investigated much later (Wach, 2015). Knight (1997) was one of the first to combine entrepreneurial orientation with the 
functioning of firms in various international cultures. He proved that entrepreneurial orientation is the crucial factor of success, determining international accomplishments of firms (Knight, 2001). Similarly, Florida (1997) proved that entrepreneurial orientation makes businesses undertake new ventures by penetrating international markets to sell their goods. Yiu, Lau and Bruton (2007) indicated innovativeness, efficiency and strategic decisions as constructs of entrepreneurial orientation. The authors added that the factors play a very important role in the internationalisation process, indicating the element related to risk-taking as particularly important. Emöke-Szidónia (2015) emphasized that small and medium-sized enterprises with high entrepreneurial orientation are leading entities of transition countries in Europe. Rant and Černe (2017) observed that differentiation via innovation positively impacts firm performance on international markets in the case of firms from the region of CEE. Numerous studies confirm a positive relation between entrepreneurial orientation and the internationalisation process (Florida, 1997; Yiu, Lau, \& Bruton, 2007; Etemad, 2015; Swoboda \& Olejnik, 2016; Tolstoy, 2018). However, this is not the final position of the researchers. Zahra and Garvis (2000) noticed a negative relation and Andersen (2010) indicated an insignificant link between entrepreneurial orientation and the internationalisation of firms. Great importance of entrepreneurial orientation, and especially of proactiveness in the internationalisation process is stressed by authors who deal with studying born globals and international new ventures, indicating that firms of this type are in their nature entrepreneurially-oriented, operating pro-actively all over the world (Sharma \& Blomstermo, 2003; Weerawardena, Mort, Liesch, \& Knight, 2007; Andersson, 2011; Andersson \& Evers, 2015).

Knowledge and its significance in the internationalisation process is the area much more recognized in the literature of the subject. Empirical research into this problem was conducted in the first place within classical and alternative concepts concerning international trade. Therefore, it was an attempt to empirically verify the influence of knowledge on export or other forms of international activity within selected concepts of international trade (Sjöholm, 1996; VIllar, Alegre, \& Pla-Barber, 2014; Geldres-Veiss, Uribe-Bórques, Coudounaris, \& Monreal-Pérez, 2016). In addition, the role of knowledge in internationalisation has been verified empirically on the grounds on the Uppsala model (Johanson \& Vahlne, 1977), the eclectic model (Prashantham, 2005; Casillas, Acedo, Gallego, \& Ramos, 2009; Mejri \& Umemoto, 2010), international entrepreneurship theories (McDougall \& Oviatt, 2000), as well as knowledge-based models (Grant, 1996). Definitely the most attention was devoted to knowledge in Johanson and Vahlne (1977) model as well as its polemical concepts created by McDougall and Oviatt (2000). Prashantham (2005) rightly observed that in spite of a seeming tension between those two approaches, in both of them we can see a specific albeit varied role of knowledge, its types and sources. Therefore, it is important to identify different types of knowledge that can have a varied impact on the internationalisation process, depending on the level of its advancement. In the stages model of internationalisation this is the market knowledge that contributes to the optimisation of the firm's resources engaged on foreign markets, thus, the lack of market knowledge becomes a substantial obstacle in the internationalisation process of firms (Forsgren, 2002; Petersen, Pedersen, \& Sharma, 2003; Johanson \& Vahlne, 2003; Johanson \& Vahlne, 2009; Xie \& Amine, 2009; Sommer \& Haug, 2011; Hsu, Chen, \& Cheng, 2013). In turn, in the context of international entrepreneurship, not only market knowledge but also specialist knowledge is particularly appreciated (McDougall \& Oviatt, 2000). 
This article adopts the typology of knowledge arising from the knowledge-based internationalisation model by Mejri and Umemoto (2010), which distinguishes two main types of knowledge: market knowledge coming from written documents, reports and explicit materials, and empirical knowledge which arises from practice and can be acquired exclusively via personal experience. The types of knowledge thus defined were juxtaposed by the authors with the internationalisation process in which they distinguished three phases according to the firm's experience level: pre-internationalisation phase, novice internationalising phase and experienced internationalising phase. Different intensity of acquiring and using specific types of knowledge falls on these phases, which is presented in Figure 1.

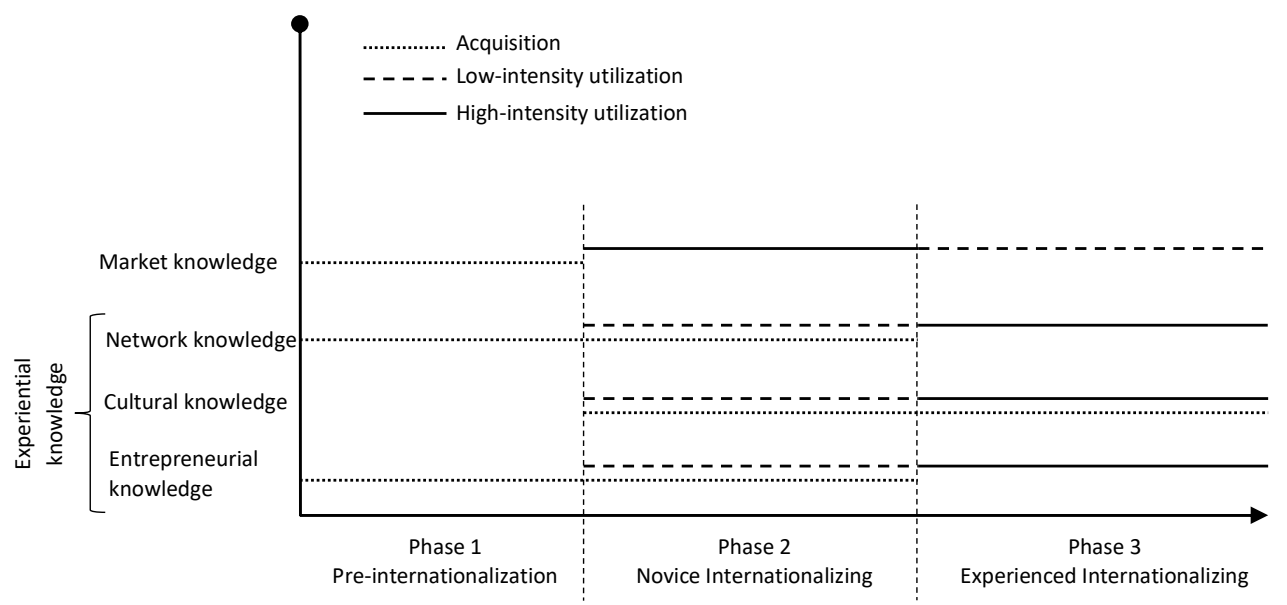

Figure 1. The role of market and experiental knowledge in the internationalisation process in the concept by Mejri and Umemoto

Source: Mejri \& Umemoto (2010, p. 162).

Market knowledge refers to the information about foreign markets, their size, competitors and regulations. The acquisition of this type of knowledge in the pre-internationalising period is of key importance for undertaking internationalisation and in the first phase of its process. Using this type of knowledge in the novice internationalising phase arises from the need to acquire any available information about the target market due to a high level of risk related to entering this market. With the increasing engagement in the internationalisation process, the intensity of the use of knowledge about the market decreases in favour of the growth of the significance of empirical knowledge.

In the empirical or experiental knowledge Mejri and Umemoto (2010) included network, sociocultural and entrepreneurial knowledge.

Network knowledge is acquired within the functioning of the firm in formal and informal social and business networks in the pre-internationalisation period and in its first phase. Knowledge acquired as a result of mutual learning and the exchange of experiences enables to reduce apprehensions towards foreign markets, which facilitates and accelerates the internationalisation of firms, particularly SMEs. It is used to a various extent on individual stages of the internationalisation process. 
Sociocultural knowledge refers to the familiarity with the values, attitudes and mindsets occurring on foreign markets. Acquisition of this type of knowledge begins with entering the internationalisation process of the firm. The intensity of the use of sociocultural knowledge grows with the level of its absorption by the firm.

Entrepreneurial knowledge refers to the recognition of market opportunities and the ways of its use. Knowledge of this type is acquired since the beginning of the firm's existence, thus still in the period preceding internationalisation, and its deepening takes place already after foreign market entry. The use of entrepreneurial knowledge on the international market grows with the experience the firm gains on it.

Amplification of the Mejri and Umemoto (2010) model with the aspect of entrepreneurial orientation is justified indirectly in studies by Omar, Aris and Nazri (2016), Åkerman (2015), Prashantham (2005), Fletcher (2004), Wiklund and Shepherd (2003). These authors proved positive influence of entrepreneurial orientation and knowledge on the firm's functioning but they did not take into account the international dimension directly. Analogically, it can be assumed that the same dependence occurs between entrepreneurial orientation, knowledge and the internalisation process (Figure 2).

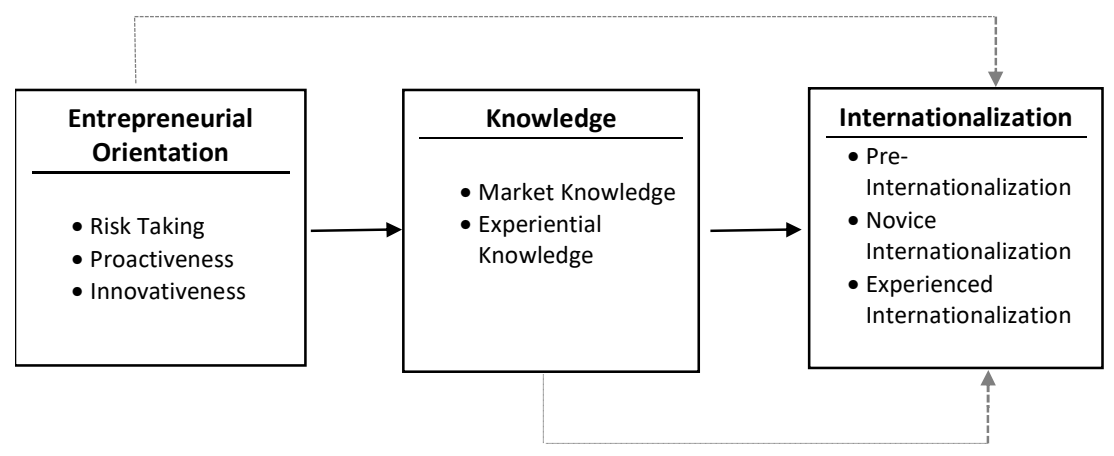

Figure 2. The impact of entrepreneurial orientation on knowledge in the internationalisation process

Source: own elaboration.

To sum up, the conducted overview of research confirms the validity of combining the influence of entrepreneurial orientation on different types of knowledge in the internationalisation process. What is more, a substantial shortage of empirical studies in this area is indicated (Gupta \& Moesel, 2007; Cui, Fan, Guo, \& Fan, 2018). On that basis, the following research hypothesis was formulated:

H: Firms with higher entrepreneurial orientation more intensely use both market knowledge and experiental knowledge (i.e. network knowledge, sociocultural knowledge, entrepreneurial knowledge), both in the novice and experienced internationalisation phase.

\section{MATERIAL AND METHODS}

As it has been already mentioned, Mejri and Umemoto's (2010) model assumes high use of market knowledge in the first period of internationalisation and its low use in the case 
of mature internationalisation. On the contrary, experiental knowledge (network, sociocultural, entrepreneurial knowledge) is subject to high use in the mature phase of internationalisation, and low use in the pioneer phase. It is worth supplementing this model with entrepreneurial orientation, since it may be expected that firms with higher entrepreneurial orientation use specific types of knowledge in the internationalisation process more intensely than firms characterised by lower entrepreneurial orientation. This concept is the authors' development of the model, combining the output of models based on the knowledge and learning process with the international entrepreneurship school.

The research sample was selected based on firms registered in Poland in REGON (National Business Register) out of which 7,100 firms were randomised and to which the survey was directed. Out of those firms only 355 gave their consent to take part in the survey (5\%). Stratified random sampling was applied in accordance with the following criteria:

1. The sample includes only internationalised firms (being at least experts);

2. The sample includes firms of different sizes but reflecting research needs, namely (a) with a small participation of micro-enterprises as the least internationalised, although they are the most numerous group in the studied population, (b) a relatively small participation of large enterprises which, although they are the smallest group in the population, are the most typical research objects in the subject of internationalisation, but it was assumed that each of those groups should be about $10-15 \%$ of the research sample, (c) with a relatively large participation of both small and medium-sized enterprises, which, according to the assumptions, should constitute $25-45 \%$ of the sample.

The survey was conducted by means of Computer Assisted Telephone Interview (CATI) technique. The survey questionnaire was divided into four thematic parts, namely: (i) the firm's characteristics, (ii) modes and scope of internationalisation, (iii) internationalisation patterns and strategies, (iv) resources and competences, (v) domestic and foreign environment, (vi) entrepreneurial orientation, (vi) characteristics of the entrepreneur.

For the needs of statistical calculations and with the use of the survey questionnaire the following variables were used:

1. IEO - international entrepreneurial orientation with the use of variables developed by Covin and Slevin (1989);

2. MARK_KNOW - market knowledge, with the use of the author's questions with measures on the Likert's scale;

3. SOCIO_KNOW - sociocultural knowledge, with the use of the authors' questions with measures on the Likert's scale;

4. NET_KNOW - network knowledge, with the use of the authors' questions with measures on the Likert's scale;

5. ENTRE_KNOW - entrepreneurial knowledge with the use of the authors' questions with measures on the Likert's scale.

Out of 7100 randomised firms from the REGON, the research sample was theoretically $5 \%$, but in reality the randomised part of the population included 3313 firms, and the final research sample was de facto $10.7 \%$. The total of 355 questionnaires were collected (Table 1). The reasons for not considering the other firms in the study were as follows:

- 28.1\% (1 991) were not internationalised firms, that is, they did not meet the first criterion; 
- 25.3\% (1 796) had a wrong phone number in the REGON, or nobody answered the phone, thus, they could not take part in the research;

- 22.9\% (1 627) refused to participate in the survey;

- $18.7 \%$ (1 331) firms came across difficulties or caused difficulties for various reasons, which made obtaining reliable responses impossible.

Table 1. Characteristics of the Research Sample

\begin{tabular}{|c|c|c|c|}
\hline \multicolumn{2}{|c|}{ Size of the firm (in \%) } & \multicolumn{2}{|c|}{ Sector of the economy (in \%) } \\
\hline $\begin{array}{l}\text { micro } \\
\text { small } \\
\text { medium-sized } \\
\text { large }\end{array}$ & $\begin{array}{l}14.1 \\
43.1 \\
29.8 \\
13.0\end{array}$ & $\begin{array}{l}\text { agriculture } \\
\text { manufacturing } \\
\text { construction } \\
\text { trade } \\
\text { services }\end{array}$ & $\begin{array}{r}1.7 \\
56.4 \\
1.9 \\
22.4 \\
17.6\end{array}$ \\
\hline \multicolumn{2}{|c|}{ Foreign ownership (in \%) } & \multicolumn{2}{|c|}{ Age of firms (in years) } \\
\hline Average & 28.0 & Average & 24 \\
\hline Min & 0 & Min & 1 \\
\hline Q1 & 0 & Q1 & 14 \\
\hline Median & 0 & Median & 20 \\
\hline Q3 & 68.5 & Q3 & 25 \\
\hline Max & 100.0 & Max & 183 \\
\hline
\end{tabular}

Source: own calculation based on the survey $(n=355)$.

Telephone interviews were conducted in the first quarter 2015, and then their results were subject to adequate statistical calculations with the use of specialist computer software Statistica PL v. 10.0 .

\section{RESULTS AND DISCUSSION}

The use of knowledge was studied in the dynamic approach in 2011 and in 2014, with the use of the retrospective managerial perception. The period of three years was related to defining internationalised firms from inception, and the literature of the subject defines them as internationalised within the first three years from inception. As for the period of time which passed from the firm's establishment to its internationalisation, it fluctuated from 0 to 61 years, but according to the median interpretation, in half of the cases it was a year and less, and in half it was a year and more. $75 \%$ of the studied firms internationalised in the 8 th year of activity at the latest, and only $10 \%$ in the whole sample undertook foreign expansion after 16 years from inception. In majority, that is in as many as $61.5 \%$ cases, we had to do with fast internationalisation (namely, three years from inception).

It was found out in the sample that in 2014 only 65 out of 355 firms were characterised by high IEO indicator (average from 'risk taking', 'proactiveness' and 'innovativeness' was equal to at least 5 ). The firms were characterised by a little, although statistically insignificant, higher market knowledge ( $t$-test -0.7819 [0.2174]). On the other hand, however, they were characterised by significantly higher network knowledge ( $t$-test -1.8061 [0.0359]). Yet, no differences between firms in terms of sociocultural knowledge consid- 
ering IEO indicator were found. Taking into account the classification made, it was observed that firms with higher IEO are characterised by statistically significant higher level of entrepreneurial knowledge ( $t$-stat=-1.7358 [0.0417]). In general, firms with the higher IEO indicator were characterised by a higher level of knowledge on three discussed levels, namely, market knowledge (statistically insignificant, though), network, entrepreneurial knowledge. Such a relationship was not discovered for sociocultural knowledge.

The decision was also made to check whether an analogous situation took place also in 2011. Based on the t-student test for medium-sized enterprises it was found out that higher IEO indicator values were accompanied then by statistically significant higher values of market knowledge ( $t$-stat -1.3852 [0.0834]). An analogous situation concerned the indicator of network knowledge ( $t$-stat -2.3523 [0.096], sociocultural knowledge ( $t$-stat $2.3755[0,081])$ and entrepreneurial knowledge (t-stat -4.7076 [0.000]. Such a relationship was not discovered for sociocultural and entrepreneurial knowledge.

The results obtained (Table 2 ) univocally prove that higher international entrepreneurial orientation intensifies the use of entrepreneurial knowledge and network knowledge on the experienced internationalisation stage (but not in its novice stage), which is the essence of international entrepreneurship. The calculations made do not enable to build general conclusions concerning experiental knowledge en bloc (no confirmation for sociocultural knowledge).

Table 2. Results of $t$ test linking four types of knowledge with EO during the novice and experienced internationalisation phases

\begin{tabular}{|c|c|c|c|c|c|c|}
\hline \multirow[t]{2}{*}{$\begin{array}{l}\text { Type of knowledge } \\
\qquad(n=353)\end{array}$} & \multicolumn{3}{|c|}{$\begin{array}{c}\text { Novice internationalisation } \\
\text { (first } 3 \text { years of operating on } \\
\text { foreign markets) }\end{array}$} & \multicolumn{3}{|c|}{$\begin{array}{c}\text { Experienced internationalisation } \\
\text { (after at least } 3 \text { years of operations } \\
\text { on foreign markets) }\end{array}$} \\
\hline & $t$-stat & $p$-value & Sig. ${ }^{a}$ & $t$-stat & $p$-value & Sig. ${ }^{a}$ \\
\hline Market knowledge & 1.3852 & 0.043 & $* *$ & -0.7819 & 0.217 & $x$ \\
\hline Network knowledge & -2.3523 & 0.096 & $*$ & -1.8061 & 0.035 & $* *$ \\
\hline Cultural knowledge & -2.3755 & 0.081 & $*$ & 1.9112 & 0.689 & $\mathrm{X}$ \\
\hline Entrepreneurial knowledge & -4.7076 & 0.000 & $* * *$ & -1.7358 & 0.041 & $* *$ \\
\hline
\end{tabular}

a significance levels: $* * *<0.01 ;{ }^{* *}<0.05 ;^{*}<0.1$.

Source: own elaboration based on the survey $(n=355)$.

In the initial internationalisation phase, in addition to market knowledge (which is compliant with theoretical bases), firms with higher entrepreneurial orientation use sociocultural knowledge (being one of the three components of experiental knowledge) more intensely, which may positively influence the course of the firm internationalisation process, thus, entrepreneurial orientation can stimulate internationalisation much earlier than it is assumed in earlier theoretical concepts which do not consider entrepreneurial orientation. Considering a very limited number of studies combining entrepreneurial orientation, knowledge and internationalisation, or rather their lack in the prior literature, it is difficult to compare and confront the obtained results. We can assume that our findings are compatible with the studies by Omar, Aris and Nazri (2016), Åkerman (2015), Prashantham (2005), Fletcher (2004), Wiklund and Shepherd (2003). 


\section{CONCLUSIONS}

Entrepreneurial orientation is nowadays one of more important issues discussed within research into internationalisation. The main components of entrepreneurial orientation: risk taking, innovativeness and proactiveness are regarded as significant causative factors of effective internationalisation. Including the aspect of knowledge in the deliberations on entrepreneurial orientation and internationalisation seems to be naturally justified on the grounds of theoretical concepts, however, it is an area rather skipped in empirical research. This article combines the issue of entrepreneurial orientation and knowledge on the example of Polish firms basing on the knowledge-based internationalisation model by Mejri and Umemoto (2010). On the basis of the conducted analysis we can find out that entrepreneurial orientation is substantial in the use of knowledge in the internationalisation process. Firms characterised by higher entrepreneurial orientation much more intensely use individual types of knowledge on various stages on internationalisation. Network knowledge is more used by those firms both in the initial and mature internationalisation. On the other hand, entrepreneurial knowledge is intensely used on the stage of mature internationalisation. Market and sociocultural knowledge is by far more explored in the initial internationalisation stage.

Therefore, based on the conducted statistical analysis we can only partially accept the verified research hypothesis, as not all types of knowledge are explored to the same extent on different internationalisation stages by firms characterised by higher entrepreneurial orientation.

The article can be of not only cognitive but also applicative character. However, it is not deprived of limitations. Firstly, it is a study conducted on the sample of Polish firms, and the research findings cannot be generalised. Moreover, it is a cross-sectional study, which makes it impossible to verify cause and effect relationships between the studied variables, which is possible only when conducting dynamic research. This article goes much further than existing research in the search for the point intermediating between entrepreneurial orientation and internationalisation, however, attention should be also paid to other factors which by means of entrepreneurial orientation influence the internationalisation process (organisational culture, management, etc.). What is more, the study adopted an assumption as for the types of knowledge, thus it is recommended to verify the research problem posed adopting also other taxonomies of knowledge. Therefore, it is recommended to carry out further research eliminating the indicated limitations. Future research may go towards international comparative analyses in the studied problem. What is more, it is worth continuing research not only on the relationship of entrepreneurial orientation and knowledge in the internationalisation process, but also on factors determining this relationship.

\section{REFERENCES}

Al Mamun, A., Kumar, N., Ibrahim, M.D., \& Bin Yusoff, M.N.H. (2017). Validating the Measurement of Entrepreneurial Orientation. Economics and Sociology, 10(4), 51-66. https://doi.org/10.14254/2071-789X.2017/10-4/5 
Åkerman, N. (2015). International opportunity realization in firm internationalization: Non-linear effects of market-specific knowledge and internationalization knowledge. Journal of International Entrepreneurship, 13(3), 242-259.

Andersen, J.A. (2010). A critical Examination of the EO-Performance Relationship. International Journal of Entrepreneurial Behavior \& Research, 16(4), 309-328.

Andersson, S. (2011). International entrepreneurship, born globals and the theory of effectuation. Journal of Small Business and Enterprise Development, 18(3), 627-643. https://doi.org/10.1108/14626001111155745

Andersson, S., \& Evers, S. (2015). International opportunity recognition in international new ventures - a dynamic managerial capabilities perspective. Journal of International Entrepreneurship, 13(3), 260-276.

Autio, E. (2017). Strategic Entrepreneurial Internationalization: A Normative Framework. Strategic Entrepreneurial Journal, 11(3), 211-227.

Casillas, J.C., Moreno, A.M., Acedo, F.J., Gallego, M.A., \& Ramos, E. (2009). An Integrative Model of the Role of Knowledge in the Internationalization Process. Journal of World Business, 44(3), 311322, https://doi.org/10.1016/j.jwb.2008.08.001

Covin, J.G., \& Slevin, D. (1989). Strategic Management of Small Firms in Hostile and Benign Environments. Strategic Management Journal, 10(1), 75-87.

Cui, L., Fan, D., Guo, F., \& Fan, Y. (2018). Explicating the relationship of entrepreneurial orientation and firm performance: Underlying mechanisms in the context of an emerging market. Industrial Marketing Management, 71, 27-40.

Emöke-Szidónia, F. (2015). International entrepreneurial orientation and performance of Romanian small and medium-sized firms: empirical assessment of direct and environment moderated relations. Procedia Economics and Finance, 32, 186-193.

Etemad, H. (2015). Entrepreneurial orientation-performance relationship in the international context. Journal of International Entrepreneurship, 13(1), 1-6.

Fletcher, D. (2004). International entrepreneurship and the small business. Entrepreneurship \& Regional Development, 16(4), 289-305.

Florida, R. (1997). The Globalization of R\&D: Results of a Survey of Foreign-affiliated R\&D Laboratories in the USA. Research Policy, 26(1), 85-103.

Forsgren, M. (2002). The concept of learning in the Uppsala internationalization process model: a critical review. International Business Review, 11(3), 257-277.

Geldres-Veiss, V.V., Uribe-Bórques, T.C., Coudounaris, N.D., \& Monreal-Pérez, J. (2016). Innovation and experiential knowledge in firm exports: Applying the initial U-model. Journal of Business Research, 69(11), 5076-5081. https://doi.org/10.1016/j.jbusres.2016.04.083

Gaweł, A. (2015). Orientacja przedsiębiorcza w wyjaśnianiu wczesnej internacjonalizacji przedsiębiorstw. Problemy Zarzqdzania, 13(4), 55-67.

Głodowska, A., Maciejewski, M., \& Wach, K. (2019). Oddziaływanie orientacji przedsiębiorczej na wykorzystanie wiedzy w procesie internacjonalizacji na przykładzie firm z Polski. Prace Komisji Geografii Przemysłu Polskiego Towarzystwa Geograficznego, 33(1).

Grant, R. (1996). Toward a knowledge based theory of the firm. Strategic Management Journal, 17(52), 109-122.

Gupta, V.K., \& Moesel, D.M. (2007). The impact of entrepreneurial orientation on knowledge management in strategic alliances: Evidence from high-technology SMEs. Proceedings of the Annual USASBE Conference, Florida, USA, 18-21 January 2007. 
Hsu, W.-T., Chen, H.-L., \& Cheng, C.-Y. (2013). Internationalization and firm performance of SMEs: the moderating effects of CEO attributes. Journal of World Business, 48(1), 1-12, https://doi.org/10.1016/j.jwb.2012.06.00

Johanson, J., \& Vahlne, J.-E. (1977). The Internationalization Process of the Firms - A Model of Knowledge Development and Increasing Foreign Market Commitments. Journal of International Business Studies, 8(1), 23-32.

Johanson, J., \& Vahlne, J.-E. (2003). Business relationship commitment and learning in the internationalization process. Journal of International Entrepreneurship, 1(1), 83-101.

Johanson, J., \& Vahlne, J.E. (2009). The Uppsala internationalization process model revisited: From liability of foreignness to liability of outsidership. Journal of International Business Studies, 40(9), 1411-1431.

Knight, G.A. (1997). Cross-cultural reliability and validity of a scale to measure firm entrepreneurial orientation. Journal of Business Venturing, 12(3), 213-225.

Knight, G.A. (2001). Entrepreneurship and Strategy in the International SME. Journal of International Management, 7(3), 155-171.

Kumar, N., Al Mamun, A., Ibrahim, M.D., \& Yusoff, M.N.H. (2018). Entrepreneurial orientation and antecedents of low-income household heads in Kelantan, Malaysia. Journal of International Studies, 11(1), 140-151. https://doi.org/10.14254/2071-8330.2017/11-1/10

Maciejewski, M., \& Wach, K. (2019). International Startups from Poland: Born Global or Born Regional?. Journal of Management and Business Administration Central Europe, 27(1).

McDougall, P.P., \& Oviatt, B.M. (2000). International Entrepreneurship: The Intersection of Two Research Paths. The Academy of Management Journal, 43(5), 902-906.

Mejri, K., \& Umemoto, K. (2010). Small- and medium-sized enterprise internationalization: Towards the knowledge-based model. Journal of International Entrepreneurship, 8(2), 156-167.

Omar, N.A., Md Aris, H., \& Nazri, M.A. (2016). The effect of entrepreneurial orientation, innovation capability and knowledge creation on firm performance: A perspective on small scale entrepreneurs. Jurnal Pengurusan, 48, 187-200.

Petersen, B., Pedersen, T., \& Sharma, D.D. (2003). The role of knowledge in firms' internationalisation process: Wherefrom and whereto? In A. Blomstermo \& D.D. Sharma (Eds.), Learning in the internationalisation process of firms (pp. 36-55). Northampton: Edward Elgar Publishing, Inc.

Prashantham, S. (2005). Toward a Knowledge-Based Conceptualization of Internationalization. Journal of International Entrepreneurship, 3(1), 37-52.

Rant, M.B., \& Černe, S.K. (2017). How to Successfully Internationalize SMEs from the CEE Region: The Role of Strategies of Differentiation and Education. Journal of Management and Business Administration Central Europe, 25(4), 2-27.

Sekliuckiene, J., Vaitkiene, R., \& Vainauskiene, V. (2018). Organisational Learning in Startup Development and International Growth. Entrepreneurial Business and Economics Review, 6(4), 125144. https://doi.org/10.15678/EBER.2018.060407

Sharma, D.D., \& Blomstermo, A. (2003).The internationalization process of born globals: A network view. International Business Review, 12(6), 739-753.

Sjöholm, F. (1996). International transfer of knowledge: The role of international trade and geographic proximity. Review of World Economics, 132(1), 97-115.

Sommer, L., \& Haug, M. (2011). Intention as a cognitive antecedent to international entrepreneurship: understanding the moderating roles of knowledge and experience. International Entrepreneurship and Management Journal, 7(1), 111-142. https://doi.org/10.1007/s11365-010-0162-z 
Swoboda, B., \& Olejnik, E. (2016). Linking Processes and Dynamic Capabilities of International SMEs: The Mediating Effect of International Entrepreneurial Orientation. Journal of Small Business Management, 54(1), 139-161.

Tolstoy, D. (2018). The Proactive Initiation of SMEs' Foreign Business Relationships. European Management Review, 15(1), 1-15. https://doi.org/10.1111/emre.12303

Villar, C., Alegre, J., \& Pla-Barber, J. (2014). Exploring the role of knowledge management practices on exports: A dynamic capabilities view. International Business Review, 23(1), 38-44. https://doi.org/10.1016/j.ibusrev.2013.08.008

Wach, K. (2015). Entrepreneurial Orientation and Business Internationalisation Process: The Theoretical Foundations of International Entrepreneurship. Entrepreneurial Business and Economics Review, 3(2), 9-24. https://doi.org/10.15678/EBER.2015.030202

Wach, K. (2017a). What Determines Entrepreneurial Orientation of Polish Internationalized Firms. Journal of Management and Financial Sciences, 10(30), 43-65.

Wach, K. (2017b). Orientacja przedsiębiorcza a wiedza w początkowym i dojrzałym etapie procesu internacjonalizacji przedsiębiorstw. Studia Ekonomiczne. Zeszyty Naukowe Uniwersytetu Ekonomicznego w Katowicach, 319, 268-282.

Wach, K. (2018). Entrepreneurial Orientation and Ownership of Internationalized Firms from Poland. Przedsiębiorczość i Zarzqdzanie, 19(2[1]), 331-341.

Wach, K., Głodowska, A., \& Maciejewski, M. (2018). Entrepreneurial Orientation, Knowledge Utilization and Internationalization of Firms. Sustainability, 10(12), 1-23. https://doi.org/10.3390/su10124711

Weerawardena, J., Mort, G.S., Liesch, P.W., \& Knight, G. (2007). Conceptualizing accelerated internationalization in the born global firm: A dynamic capabilities perspective. Journal of World Business, 42(3), 294-306. https://doi.org/10.1016/j.jwb.2007.04.004

Wiklund, J., \& Shepherd, D. (2003). Knowledge-based resources, entrepreneurial orientation, and the performance of small and medium sized businesses. Strategic Management Journal, 24(13), 1307-1314.

Xie, Y., \& Amine, L. (2009). Social networks and the internationalization of Chinese entrepreneurs. Global Business and Organizational Excellence, 29(1), 61-78. https://doi.org/10.1002/joe.20299

Yiu, D.W., Lau, C., \& Bruton, G.D. (2007). International venturing by emerging economy firms: The effects of firm capabilities, home country networks, and corporate entrepreneurship. Journal of International Business Studies, 38(4), 519-540.

Zahra, S., \& Garvis, D. (2000). International Corporate Entrepreneurship and Firm Performance: the Moderating Effect of International Environmental Hostility. Journal of Business Venturing, 15(5-6), 469-492. 


\section{Authors}

The contribution share of authors is equal and amounted to $33 \%$ each of them.

\section{Agnieszka Głodowska}

Assistant Professor in the Department of International Trade, PhD in economics, author of the publications on international trade and international entrepreneurship, member of editorial boards of 'Entrepreneurial Business and Economics Review' (Scopus, ESCI WoS), 'International Journal of Managerial Studies and Research' (USA), 'International Entrepreneurship' (Poland). Research interests: international entrepreneurship, finance and risk in international business.

Correspondence to: Dr Agnieszka Głodowska, Cracow University of Economics, ul. Rakowicka 27, 31-510 Kraków, Poland, e-mail: glodowsa@uek.krakow.pl

ORCID (ㄷ) https://orcid.org/0000-0002-5317-8625

\section{Marek Maciejewski}

Assistant Professor in the Department of International Trade, PhD in economics, author of publications on international trade, scientific secretary of the journal 'International Entrepreneurship'. Correspondence to: Dr Marek Maciejewski, Cracow University of Economics, ul. Rakowicka 27, 31-510 Kraków, Poland, e-mail: maciejem@uek.krakow.pl

ORCID (1) https://orcid.org/0000-0003-1343-3764

\section{Krzysztof Wach}

Associate Professor (Prof. UEK) of the Cracow University of Economics (Poland). Habilitated doctor of economics (DEcon), PhD in management, specialist in international entrepreneurship, author of several books and over 150 scientific articles, editor-in-chief of the scientific quarterly 'Entrepreneurial Business and Economics Review' (ESCI WoS, Scopus), member of editorial boards of several scientific journals, including 'European Journal of International Management' (SSCI WoS); in the years 2012-2018 an OECD and the European Commission national expert for entrepreneurship, participant of various international education and research projects (e.g. Jean Monnet, Atlantis, International Visegrad Fund IVF, Central European Initiative CEI), visiting professor in various foreign universities, including USA, UK, Spain, Croatia, China, Taiwan, Austria, Slovakia and Ukraine.

Correspondence to: Prof. Krzysztof Wach, PhD, Cracow University of Economics, ul. Rakowicka 27, 31-510 Kraków, Poland, e-mail: wachk@uek.krakow.pl

ORCID ㄴ) http://orcid.org/0000-0001-7542-2863

\section{Acknowledgements and Financial Disclosure}

The article came into being within the OPUS 4 project entitled 'Behaviours of Polish firms in the internationalisation process in the perspective of international entrepreneurship', which was realized in the years 2013-2018 at the Faculty of Economics and International Relations of Cracow University of Economics. The project was financed from the funds of the National Science Centre (NCN) granted on the base of the decision number DEC-2012/07/B/HS4/00701.

\section{Copyright and License}

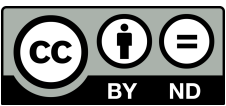

This article is published under the terms of the Creative Commons

Attribution - NoDerivs (CC BY-ND 4.0) License

http://creativecommons.org/licenses/by-nd/4.0/

Published by the Centre for Strategic and International Entrepreneurship - Krakow, Poland 
